\title{
A comparative study of quality issues of garment export houses between Delhi and Bangalore
}

\section{ARUSHI JABEEN AND NAZNEEN JABEEN}

Received: 10.10.2017; Revised: 10.11.2017; Accepted: 25.11.2017

See end of the paper for authors' affiliations NAZNEEN JABEEN

Department of Home Science, M.L.\& J

N.K.Girls College, SAHARANPUR (UP).INDIA
DBSTRACT : The garments are now has gain the importance in the present day society. The design, fitting, color and type of fabric are important factors in selection of garments. The businesses of readymade garments have now taken in a leap in a large section of society particularly in cities army and other forces personals. Many Industries are now involved in garment making throughout the world. India is also in this business and earns millions of rupees as foreign exchange through export of garments. In the present study the evaluation of different process of garment making were evaluated for different Industries of Delhi and Bangalore. In fact the process is now industrialized to produce large quantities of products. The industrialization of a process need a careful watch at each stage of Process better quality material, sophisticated machines and checking of the product at each step to point out any defect in process of material. Every industry may not have the same type of process, machines or man power engaged in the process of garment making.

KEY WORDS: Garment, Garment Making, Export, Process, Quality, Quality Material

HOW TO CITE THIS PAPER : Jabeen, Arushi and Jabeen, Nazneen (2017). A comparative study of quality issues of garment export houses between Delhi and Bangalore. Asian J. Home Sci., 12 (2) : 622-626, DOI: 10.15740/HAS/AJHS/12.2/622-626. 